\title{
Pemetaan Kualitas Air Sumur Bor Warga Kota Sorong
}

\author{
Nur Afdaliah ${ }^{1}$, Hendrik Pristianto ${ }^{2}$ \\ ${ }^{1,2)}$ Program Studi Teknik Sipil Universitas Muhammadiyah Sorong \\ E-mail : tekniksipilsorong@gmail.com
}

\begin{abstract}
Abstrak
Air merupakan kebutuhan dasar bagi kehidupan khususnya bagi manusia yang selama hidupnya selalu memerlukan air, namun demikian air dapat menjadi malapetaka bilamana tidak tersedia dalam kondisi yang benar. Kualitas air menyatakan tingkat kesesuaian air terhadap penggunaan tertentu dalam memenuhi kebutuhan hidup manusia, mulai dari air untuk memenuhi kebutuhan langsung seperti minum dan kebutuhan sehari-hari lainnya, air irigasi atau pertanian, peternakan, perikanan, rekreasi dan transportasi. Kualitas air dapat diketahui dengan melakukan pengujian tertentu terhadap air tersebut. Pengujian yang biasa dilakukan adalah uji kimia, dan fisika. Pada penelitian ini bertujuan untuk mengidentifikasi serta memetakan kualitas air sumur bor warga Kota Sorong berdasarkan parameter fisik dan kimia. Pengukuran parameter fisik terdiri dari turbidity (kekeruhan), salinitas, konduktivitas, TDS, ORP dan parameter kimia terdiri dari pH, DO, dan Fe. Sampel yang digunakan pada penelitian ini terdiri dari empat belas titik sumur bor warga yang tersebar di Kota Sorong, data hasil pengukuran sampel yang dilakukan secara in-situ (pengukuran langsung di lapangan). Dari hasil analisa $28,57 \%$ titik sampel yang memenuhi baku mutu kelas II, III dan IV, 21,43\% yang memenuhi baku mutu kelas III, dan $50 \%$ titik sampel yang hanya memenuhi baku mutu kelas IV. Adapun hasil kualitas air sumur bor warga Kota Sorong diolah dengan menggunakan aplikasi sofware untuk pemetaan arcgis dengan parameter TDS $100 \%$ memenuhi baku mutu, pH 92,8 \% memenuhi baku mutu, FE $50 \%$ memenuhi baku mutu, dan DO untuk kelas II $25 \%$ memenuhi baku mutu, kelas III 21,4\% memenuhi baku mutu, dan kelas IV $50 \%$ memenuhi baku mutu.
\end{abstract}

Kata kunci : Air Tanah, Kualitas Air, Pemetaan, Sumur Bor Warga

\section{Pendahuluan}

Kota Sorong merupakan satu-satunya kota yang ada di Provinsi Papua Barat Indonesia, yang mempunyai luas wilayah mencapai $1.105,00 \mathrm{~km}^{2}$, atau sekitar $1.13 \%$ dari total luas wilayah Papua Barat. Wilayah kota ini berada pada ketinggian 3 meter dari permukaan laut dan suhu udara minimum di Kota Sorong sekitar $23,1^{\circ} \mathrm{C}$ dan suhu udara maksimum sekitar $33,7{ }^{\circ} \mathrm{C}$. Curah hujan tercatat $2.911 \mathrm{~mm}$, dan curah hujan cukup merata sepanjang tahun.

Kualitas air menyatakan tingkat kesesuaian air terhadap penggunaan tertentu dalam memenuhi kebutuhan hidup manusia, mulai dari air untuk memenuhi kebutuhan langsung seperti minum dan kebutuhan sehari-hari lainnya, air irigasi atau pertanian, peternakan, perikanan, rekreasi dan transportasi. Kualitas air dapat diketahui dengan melakukan pengujian tertentu terhadap air tersebut. Pengujian yang biasa dilakukan adalah uji kimia, dan fisika.

Saat ini, masalah utama yang dihadapi oleh sumber daya air meliputi kuantitas air yang sudah tidak mampu memenuhi kebutuhan yang terus meningkat dan kualitas air untuk keperluan domestik yang semakin menurun. Pengelolaan sumber daya air sangat penting, agar dapat dimanfaatkan secara berkelanjutan dengan tingkat mutu yang diinginkan. Salah satu langkah pengelolaan yang dilakukan adalah pemantauan dan interpretasi data kualitas air, mencakup kualitas fisika dan kimia. Berdasarkan keterangan dari masyarakat yang tinggal di kompleks Harapan Indah Km.10, kualitas air pada sumur bor yang digunakan biasanya berbau, mempunyai rasa asin, dan berwarna agak kecoklatan.

\section{Tujuan Penelitian}

Penelitian ini bertujuan untuk :

1. Bagaimana kualitas air sumur bor warga Kota Sorong berdasarkan parameter fisik dan parameter kimia?

2. Bagaimana gambaran kualitas air sumur bor warga kota sorong?

\section{Metode}

\section{Tahapan}

1. Mengumpulkan data di wilayah Kota Sorong meliputi pengumpulan data foto udara melalui google earth, pengambilan titik koordinat sampel dan pengambilan sampel air sumur bor.

2. Melakukan pengamatan langsung terhadap kondisi dan kualitas air sumur bor.

3. Mengolah data hasil pengukuran sampel yang dilakukan secara in-situ (pengukuran langsung di lapangan).

4. Menentukan hasil analisa data 
Metode penelitian yang dilakukan dapat dilihat pada Gambar 1 berikut ini.

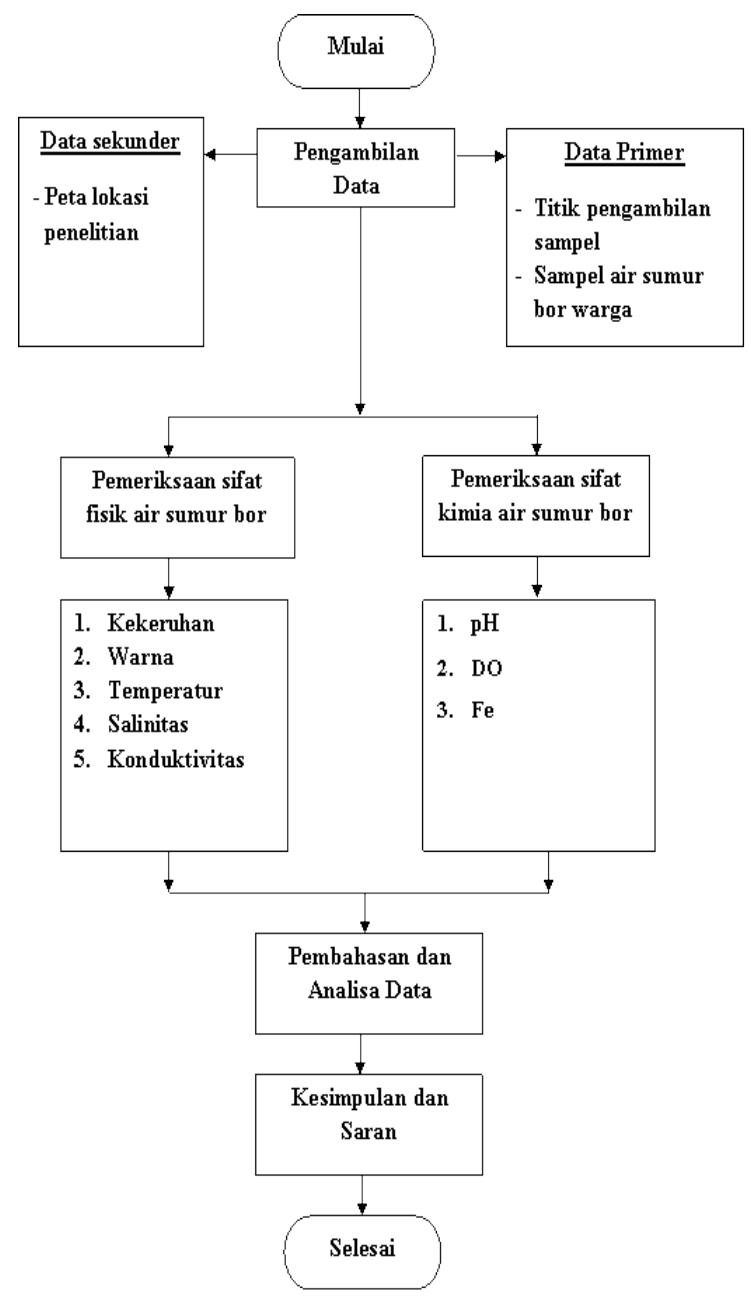

Gambar 1. Diagram Alur Penelitian

\section{Hasil Penelitian}

Pengambilan sampel dilakukan di empat belas (14) titik penelitian yang terdiri dari Km. 14, Moyo Km.13, Jl. Dorowati Km.12, Harapan Indah Km.10, Kampung Bugis Km.10, Perumahan Rawa Indah, Melati Raya, Jl. F. Kalasuat Malanu, Kampus UMS, Jl. Masjid Raya, Jl. Ferry, Jl. Sultan Hasanuddin, RSUD Kab. Sorong, Rufei. Adapun hasil pengukuran parameter fisik (Kekeruhan, Konduktivitas, Salinitas, TDS, ORP dan parameter kimia ( $\mathrm{pH}, \mathrm{DO}, \mathrm{FE})$ air di seluruh titik penelitian dapat dilihat pada tabel dibawah ini.

Tabel 1. Hasil pengujian parameter fisik dan kimia air

\begin{tabular}{ccccccccc}
\hline \multicolumn{1}{c}{$\begin{array}{c}\text { Yode } \\
\text { Titik }\end{array}$} & $\begin{array}{c}\text { Turbidity } \\
(\mathrm{NTU})\end{array}$ & $\begin{array}{c}\text { Cond. } \\
(\mu \mathrm{S})\end{array}$ & $\begin{array}{c}\text { Salt. } \\
(\mathrm{ppm})\end{array}$ & $\begin{array}{c}\text { TDS } \\
(\mathrm{ppm})\end{array}$ & $\begin{array}{c}\text { ORP } \\
(\mathrm{mV})\end{array}$ & $\mathrm{pH}$ & $\begin{array}{c}\text { D0 } \\
(\mathrm{mg} / \mathrm{L})\end{array}$ & $\begin{array}{c}\text { FE } \\
(\mathrm{mg} / \mathrm{L})\end{array}$ \\
\hline S1 & 0,71 & 349 & 177 & 223 & 139 & 7,4 & 3,98 & 0,2 \\
S2 & 2,25 & 813 & 412 & 452 & 35 & 8,0 & 4,84 & 0,2 \\
S3 & 1,38 & 473 & 242 & 319 & -61 & 7,4 & 1,83 & 0,2 \\
S4 & 2,97 & 588 & 293 & 222 & 24 & 7,4 & 1,42 & 0,8 \\
S5 & 0,26 & 311 & 155 & 181 & 27 & 71 & 0,94 & 0.2
\end{tabular}

\section{Pembahasan}

Dari hasil analisa data kualitas air sumur bor warga Kota Sorong berdasarkan parameter fisik dan kimia, pada penelitian hanya 4 parameter yang terdapat dalam baku buku menurut PP No. 82 tahun 2001 yaitu parameter fisik TDS dan parameter kimia $\mathrm{pH}, \mathrm{DO}$, dan FE.

Tabel 2. Klasifikasi baku mutu dititik (S1)

\begin{tabular}{ccccccc}
\hline \multicolumn{5}{c}{$\begin{array}{c}\text { Hasil } \\
\text { Analisa }\end{array}$} & Baku Mutu (PP N0.82 Tahun 2001) & Keterangan \\
Parameter & & & & & \\
& $(\mathrm{Sl})$ & Kls I & Kls II & Kls III & Kls IV & \\
\hline Fisik & & & & & & \\
TDS & 223 & 1000 & 1000 & 1000 & 2000 & TDS masuk dalam semua kriteria kelas baku mutu \\
Kimia & & & & & & \\
pH & 7,4 & $6-9$ & $6-9$ & $6-9$ & $5-9$ & pH masuk dalam semua kriteria kelas baku mutu \\
D0 & 3,98 & 6 & 4 & 3 & 0 & D0 masuk dalam kriteria baku mutu kelas III dan IV \\
FE & 0,2 & 0,3 & $(-)$ & $(-)$ & $(-)$ & Fe masuk dalam semua kriteria kelas baku mutu \\
\hline
\end{tabular}

Tabel 3. Klasifikasi baku mutu dititk (S2)

\begin{tabular}{cccccccc}
\hline & $\begin{array}{c}\text { Hasil } \\
\text { Analisa }\end{array}$ & Baku Mutu (PP No.82 Tahun 2001) & Keterangan \\
Parameter & (S2) & Kls I & Kls II & Kls III & Kls IV & \\
\hline Fisik & & & & & & \\
TDS & 452 & 1000 & 1000 & 1000 & 2000 & TDS masuk dalam semua kriteria kelas baku mutu \\
Kimia & & & & & & \\
pH & 8,0 & $6-9$ & $6-9$ & $6-9$ & $5-9$ & pH masuk dalam semua kriteria kelas baku mutu \\
D0 & 4,84 & 6 & 4 & 3 & 0 & D0 masuk dalam kriteria baku mutu kelas II, III dan IV \\
FE & 0,2 & 0,3 & $(-)$ & $(-)$ & $(-)$ & Fe masuk dalam semua kriteria kelas baku mutu \\
\hline
\end{tabular}

Tabel 4. Klasifikasi baku mutu dititk (S3)

\begin{tabular}{cccccccc}
\hline & $\begin{array}{c}\text { Hasil } \\
\text { Analisa }\end{array}$ & \multicolumn{2}{c}{ Baku Mutu (PP No.82 Tahun 2001) } & Keterangan \\
Parameter & (S3) & Kls I & Kls II & Kls III & Kls IV & \\
\hline Fisik & & & & & & \\
TDS & 319 & 1000 & 1000 & 1000 & 2000 & TDS masuk dalam semua kriteria kelas baku mutu \\
Kimia & & & & & & \\
pH & 7,4 & $6-9$ & $6-9$ & $6-9$ & $5-9$ & pH masuk dalam semua kriteria kelas baku mutu
\end{tabular}


Tabel 5. Klasifikasi baku mutu dititk (S4)

\begin{tabular}{|c|c|c|c|c|c|c|}
\hline \multirow{2}{*}{ Parameter } & \multirow{2}{*}{$\begin{array}{c}\text { Hasil } \\
\text { Analisa } \\
\text { (54) }\end{array}$} & \multicolumn{4}{|c|}{ Baku Mutu (PP No.82 Tahun 2001) } & \multirow{2}{*}{ Keterangan } \\
\hline & & Kls I & $\mathrm{Kls} \| \mathrm{I}$ & Kls III & $\mathrm{Kls} \mathrm{IV}$ & \\
\hline \multicolumn{7}{|l|}{ Fisik } \\
\hline TDS & 222 & 1000 & 1000 & 1000 & 2000 & TDS masuk dalam semua kriteria kelas baku mutu \\
\hline \multicolumn{7}{|l|}{ Kimia } \\
\hline $\mathrm{pH}$ & 7,4 & $6-9$ & $6-9$ & 6.9 & 5.9 & pH masulk dalam semua kriteria kelas baku mutu \\
\hline D0 & 1,42 & 6 & 4 & 3 & 0 & DO hanya memenuhi kriteria baku mutu kelas IV \\
\hline $\mathrm{FE}$ & 0,8 & 0,3 & $(-)$ & $(-)$ & $(-)$ & Fe tidak masuk dalam kriteria baku mutu kelas I \\
\hline
\end{tabular}

Tabel 6. Klasifikasi baku mutu dititk (S5)

\begin{tabular}{cccccccc}
\hline & $\begin{array}{c}\text { Hasil } \\
\text { Analisa }\end{array}$ & Baku Mutu (PP No.82 Tahun 2001) & Keterangan \\
Parameter & & & & & & \\
& $($ S5) & Kls I & Kls II & Kls III & Kls IV & \\
\hline Fisik & & & & & & \\
TDS & 181 & 1000 & 1000 & 1000 & 2000 & TDS masuk dalam semua kriteria kelas baku mutu \\
Kimia & & & & & & \\
pH & 7,1 & $6-9$ & $6-9$ & $6-9$ & $5-9$ & pH masuk dalam semua kriteria kelas baku mutu \\
D0 & 0,94 & 6 & 4 & 3 & 0 & D hanya memenuhi kriteria baku mutu kelas IV \\
FE & 0,2 & 0,3 & $(-)$ & $(-)$ & $(-)$ & Fe masuk dalam semua kriteria kelas baku mutu \\
\hline
\end{tabular}

Tabel 7. Klasifikasi baku mutu dititk (S6)

\begin{tabular}{cccccccc}
\hline & $\begin{array}{c}\text { Hasil } \\
\text { Analisa }\end{array}$ & \multicolumn{2}{c}{ Baku Mutu (PP No.82 Tahun 2001) } & Keterangan \\
Parameter & & & & & \\
& $($ S6) & Kls I & Kls II & Kls III & Kls IV & \\
\hline Fisik & & & & & & \\
TDS & 323 & 1000 & 1000 & 1000 & 2000 & TDS masuk dalam semua kriteria kelas baku mutu \\
Kimia & & & & & & \\
pH & 7,1 & $6-9$ & $6-9$ & $6-9$ & $5-9$ & pH masuk dalam semua kriteria kelas baku mutu \\
D0 & 2,11 & 6 & 4 & 3 & 0 & D0 hanya memenuhi kriteria baku mutu kelas IV \\
FE & 0,2 & 0,3 & $(-)$ & $(-)$ & $(-)$ & Fe masuk dalam semua kriteria kelas baku mutu \\
\hline
\end{tabular}

Tabel 8. Klasifikasi baku mutu dititk (S7)

\begin{tabular}{cccccccc}
\hline \multicolumn{5}{c}{$\begin{array}{c}\text { Hasil } \\
\text { Analisa }\end{array}$} & \multicolumn{2}{c}{ Baku Mutu (PP No.82 Tahun 2001) } & Keterangan \\
& Parameter & & & & & \\
& (S7) & Kls I & Kls II & Kls III & Kls IV & \\
\hline Fisik & & & & & & \\
TDS & 191 & 1000 & 1000 & 1000 & 2000 & TDS masuk dalam semua kriteria kelas baku mutu \\
Kimia & & & & & & \\
pH & 6,4 & $6-9$ & $6-9$ & $6-9$ & $5-9$ & pH masuk dalam semua kriteria kelas baku mutu \\
D0 & 4,66 & 6 & 4 & 3 & 0 & D0 masuk dalam kriteria kelas II, III dan IV \\
FE & 3,8 & 0,3 & $(-)$ & $(-)$ & $(-)$ & Fe tidak masuk dalam kriteria baku mutu kelas I \\
\hline
\end{tabular}

Tabel 9. Klasifikasi baku mutu dititk (S8)

\begin{tabular}{ccccccc}
\hline & $\begin{array}{c}\text { Hasil } \\
\text { Analisa }\end{array}$ & Baku Mutu (PP No.82 Tahun 2001) & Keterangan \\
Parameter & (S8) & Kls I & Kls II & Kls III & Kls IV & \\
\hline Fisik & & & & & & \\
TDS & 157 & 1000 & 1000 & 1000 & 2000 & TDS masuk dalam semua kriteria kelas baku mutu \\
Kimia & & & & & & \\
pH & 6,8 & $6-9$ & $6-9$ & $6-9$ & $5-9$ & pH masuk dalam semua kriteria kelas baku mutu \\
D0 & 5,06 & 6 & 4 & 3 & 0 & D0 masuk dalam kriteria kelas II, III dan IV \\
FE & 0,8 & 0,3 & $(-)$ & $(-)$ & $(-)$ & Fe tidak masuk dalam kriteria baku mutu kelas I \\
\hline
\end{tabular}

Tabel 10. Klasifikasi baku mutu dititk (S9)

\begin{tabular}{cccccccc}
\hline & $\begin{array}{c}\text { Hasil } \\
\text { Analisa }\end{array}$ & Baku Mutu (PP No.82 Tahun 2001) & Keterangan \\
Parameter & (S9) & Kls I & Kls II & Kls III & Kls IV & \\
\hline Fisik & & & & & & \\
TDS & 195 & 1000 & 1000 & 1000 & 2000 & TDS masuk dalam semua kriteria kelas baku mutu \\
Kimia & & & & & & \\
pH & 6,3 & $6-9$ & $6-9$ & $6-9$ & $5-9$ & pH masuk dalam semua kriteria kelas baku mutu \\
D0 & 3,44 & 6 & 4 & 3 & 0 & D0 masuk dalam kriteria baku mutu kelas III dan IV \\
FE & 0,4 & 0,3 & $(-)$ & $(-)$ & $(-)$ & Fe tidak masuk dalam kriteria baku mutu kelas I \\
\hline
\end{tabular}

Tabel 11. Klasifikasi baku mutu dititk (S10)

\begin{tabular}{cccccccc}
\hline & $\begin{array}{c}\text { Hasil } \\
\text { Analisa }\end{array}$ & \multicolumn{3}{c}{ Baku Mutu (PP No.82 Tahun 2001) } & Keterangan \\
Parameter & $(\mathrm{S10})$ & $\mathrm{Kls}$ I & $\mathrm{Kls}$ II & $\mathrm{Kls}$ III & $\mathrm{Kl}$ IV & \\
\hline Fisik & & & & & & \\
TDS & 864 & 1000 & 1000 & 1000 & 2000 & TDS masuk dalam semua kriteria kelas baku mutu \\
Kimia & & & & & & \\
pH & 6,5 & $6-9$ & $6-9$ & $6-9$ & $5-9$ & pH masuk dalam semua kriteria kelas baku mutu \\
D0 & 2,25 & 6 & 4 & 3 & 0 & D0 hanya memenuhi kriteria baku mutu kelas IV \\
FE & 0,8 & 0,3 & $(-)$ & $(-)$ & $(-)$ & Fe tidak masuk dalam kriteria baku mutu kelas I \\
\hline
\end{tabular}


Tabel 12. Klasifikasi baku mutu dititk (S11)

\begin{tabular}{cccccccc}
\hline & $\begin{array}{c}\text { Hasil } \\
\text { Analisa }\end{array}$ & Baku Nutu (PP No.82 Tahun 2001) & Keterangan \\
Parameter & (S11) & Kls I & Kls II & Kls III & Kls IV & \\
\hline Fisik & & & & & & \\
TDS & 13 & 1000 & 1000 & 1000 & 2000 & TDS masuk dalam semua kriteria kelas baku mutu \\
Kimia & & & & & & \\
pH & 5,6 & $6-9$ & $6-9$ & $6-9$ & $5-9$ & pH hanya memenuhi kriteria baku mutu kelas IV \\
D0 & 4,7 & 6 & 4 & 3 & 0 & D0 masuk dalam kriteria baku mutu kelas II, III dan IV \\
FE & 0,2 & 0,3 & $(-)$ & $(-)$ & $(-)$ & Fe masuk dalam semua kriteria kelas baku mutu \\
\hline
\end{tabular}

Tabel 13. Klasifikasi baku mutu dititk (S12)

\begin{tabular}{cccccccc}
\hline \multicolumn{5}{c}{$\begin{array}{c}\text { Hasil } \\
\text { Analisa }\end{array}$} & \multicolumn{2}{c}{ Baku Mutu (PP No.82 Tahun 2001) } & Keterangan \\
Parameter & $($ S12) & Kls I & Kls II & Kls III & Kls IV & \\
\hline Fisik & & & & & & \\
TDS & 439 & 1000 & 1000 & 1000 & 2000 & TDS masuk dalam semua kriteria kelas baku mutu \\
Kimia & & & & & & \\
pH & 6,7 & $6-9$ & $6-9$ & $6-9$ & $5-9$ & pH masuk dalam semua kriteria kelas baku mutu \\
D0 & 3,46 & 6 & 4 & 3 & 0 & D0 masuk dalam kriteria baku mutu kelas III dan IV \\
FE & 0,8 & 0,3 & $(-)$ & $(-)$ & $(-)$ & Fe tidak masuk dalam kriteria baku mutu kelas I \\
\hline
\end{tabular}

Tabel 14. Klasifikasi baku mutu dititk (S13)

\begin{tabular}{cccccccc}
\hline & $\begin{array}{c}\text { Hasil } \\
\text { Analisa }\end{array}$ & \multicolumn{2}{c}{ Baku Mutu (PP No.82 Tahun 2001) } & Keterangan \\
Parameter & $($ S13) & Kls I & Kls II & Kls III & Kls IV & \\
\hline Fisik & & & & & & \\
TDS & 353 & 1000 & 1000 & 1000 & 2000 & TDS masuk dalam semua kriteria kelas baku mutu \\
Kimia & & & & & & \\
pH & 6,6 & $6-9$ & $6-9$ & $6-9$ & $5-9$ & pH masuk dalam semua kriteria kelas baku mutu \\
D0 & 2,16 & 6 & 4 & 3 & 0 & D0 hanya memenuhi kriteria baku mutu kelas IV \\
FE & 0,8 & 0,3 & $(-)$ & $(-)$ & $(-)$ & Fe tidak masuk dalam kriteria baku mutu kelas I \\
\hline
\end{tabular}

Tabel 15. Klasifikasi baku mutu dititk (S14)

\begin{tabular}{|c|c|c|c|c|c|c|}
\hline \multirow{2}{*}{ Parameter } & \multirow{2}{*}{$\begin{array}{c}\text { Hasil } \\
\text { Analisa } \\
\text { (S14) }\end{array}$} & \multicolumn{4}{|c|}{ Baku Mutu (PP No.82 Tahun 2001) } & \multirow{2}{*}{ Keterangan } \\
\hline & & Kls I & Kls II & Kls III & $\mathrm{Kls}$ IV & \\
\hline \multicolumn{7}{|l|}{ Fisik } \\
\hline TDS & 746 & 1000 & 1000 & 1000 & 2000 & TDS masuk dalam semua kriteria kelas baku mutu \\
\hline \multicolumn{7}{|l|}{ Kimia } \\
\hline $\mathrm{pH}$ & 7 & $6-9$ & $6-9$ & $6-9$ & $5-9$ & pH masuk dalam semua kriteria kelas baku mutu \\
\hline D0 & 2,67 & 6 & 4 & 3 & 0 & D0 hanya memenuhi kriteria baku mutu kelas IV \\
\hline $\mathrm{FE}$ & 0,2 & 0,3 & $(-)$ & $(-)$ & $(-)$ & Fe masuk dalam semua kriteria kelas baku mutu \\
\hline
\end{tabular}

\section{Peta Kontur parameter fisik}

a) Salinitas

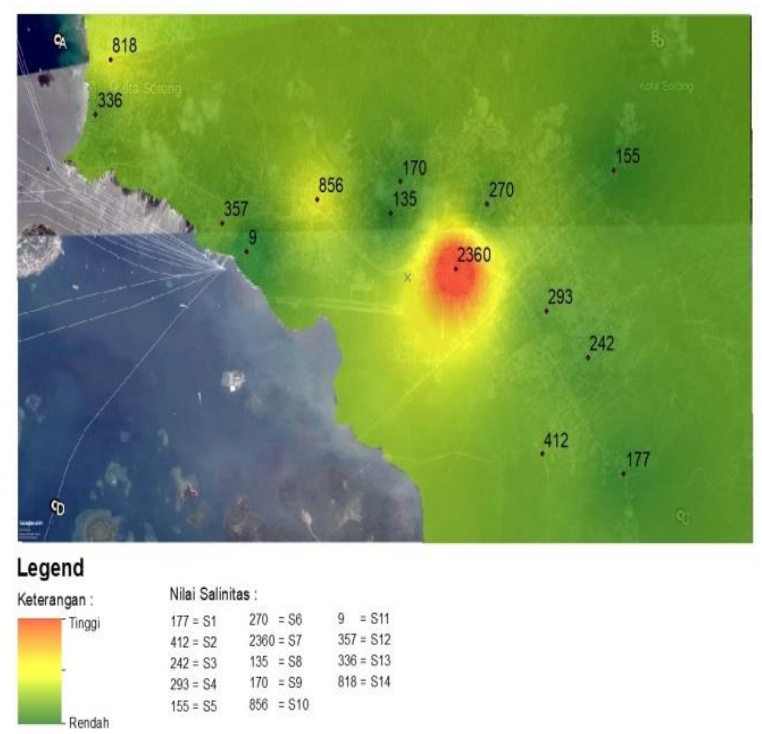

Gambar 2. Kontur nilai Salinitas penelitian

Dari gambar kontur untuk parameter Salinitas diatas, nilai salinitas tertinggi yaitu $2360 \mathrm{ppm}$ pada titik S7 dimana titik tersebut berlokasi di Melati Raya Km.9 dengan jarak 2.382,56 meter dari garis pantai, dan nilai salinitas terendah yaitu $9 \mathrm{ppm}$ berada pada titik S11 dimana titik tersebut berlokasi di Jl. Fery dengan jarak 438,65 meter dari garis pantai. Dilihat dari gradasi warna parameter salinitas sumur bor warga Kota Sorong pada titik sampel penelitian relatif lebih rendah.

b) Konduktivitas

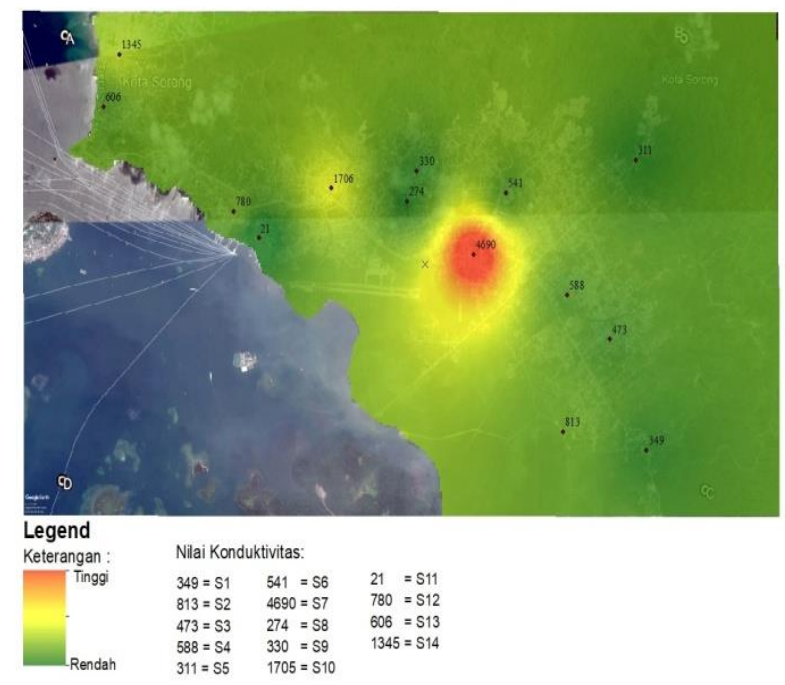

Gambar 3. Kontur nilai Salinitas penelitian

Dari gambar kontur untuk parameter Salinitas diatas, nilai salinitas tertinggi yaitu $2360 \mathrm{ppm}$ pada titik S7 dimana titik tersebut berlokasi di Melati Raya Km.9 dengan jarak 2.382,56 meter dari garis pantai, dan nilai salinitas terendah yaitu $9 \mathrm{ppm}$ 
berada pada titik S11 dimana titik tersebut berlokasi di Jl. Fery dengan jarak 438,65 meter dari garis pantai. Dilihat dari gradasi warna parameter salinitas sumur bor warga Kota Sorong pada titik sampel penelitian lebih relatif rendah.

c) TDS

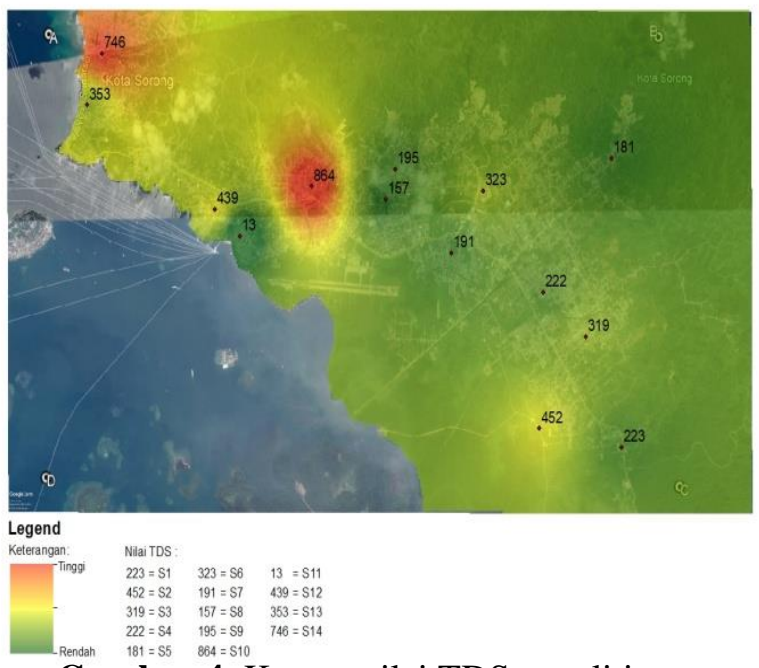

Gambar 4. Kontur nilai TDS penelitian

Dari gambar kontur untuk parameter TDS, nilai TDS tertinggi yaitu 864 ppm pada titik S10 dimana titik tersebut berlokasi di Jl. Maasjid Raya dengan jarak 438,65 meter dari garis pantai, dan nilai TDS terendah yaitu $-0,61 \mathrm{mV}$ berada pada titik $\mathrm{S} 3$ dimana titik tersebut berlokasi di Jl. Dorowati Km.12 dengan jarak 1.792,39 meter dari garis pantai. Dilihat dari warna kontur parameter TDS sumur bor warga Kota Sorong pada titik sampel penelitian lebih dominan rendah.

d) ORP

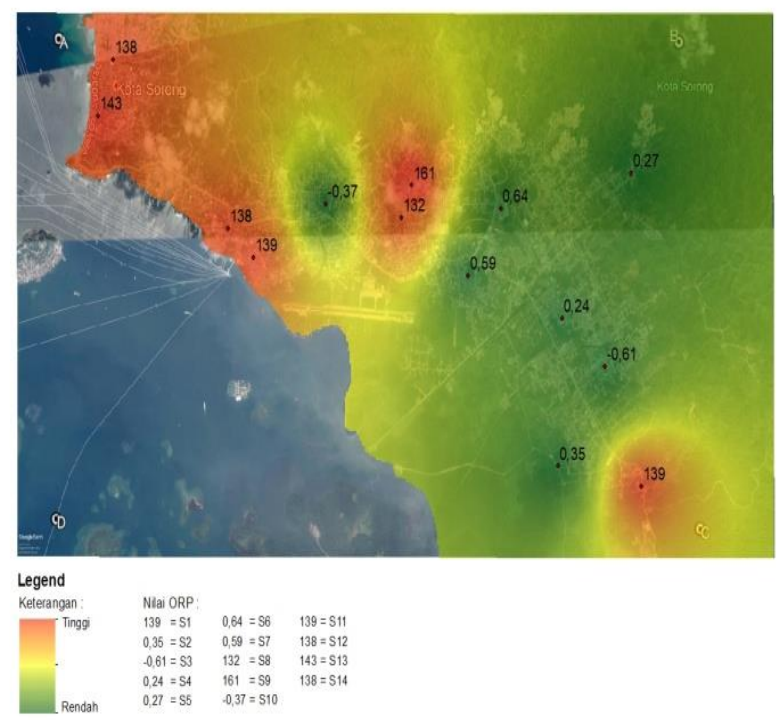

Gambar 5. Kontur nilai ORP penelitian

"Dari gambar kontur untuk parameter ORP diatas, nilai ORP tertinggi yaitu $139 \mathrm{mV}$ pada titik
S11 dimana titik tersebut berlokasi di Jl. Fery dengan jarak 438,65 meter dari garis pantai, dan nilai ORP terendah yaitu $-37 \mathrm{mV}$ berada pada titik S3 dimana titik tersebut berlokasi di Jl. Masjid dengan jarak 1.792,39 meter dari garis pantai. Dilihat dari gradasi warna parameter ORP untuk sumur bor warga Kota Sorong pada titik penelitian bagian Sorong Barat relatif tinggi, sedangkan dibagian Sorong Timur nilai ORPnya cenderung lebih rendah.

\section{e) Turbidity}

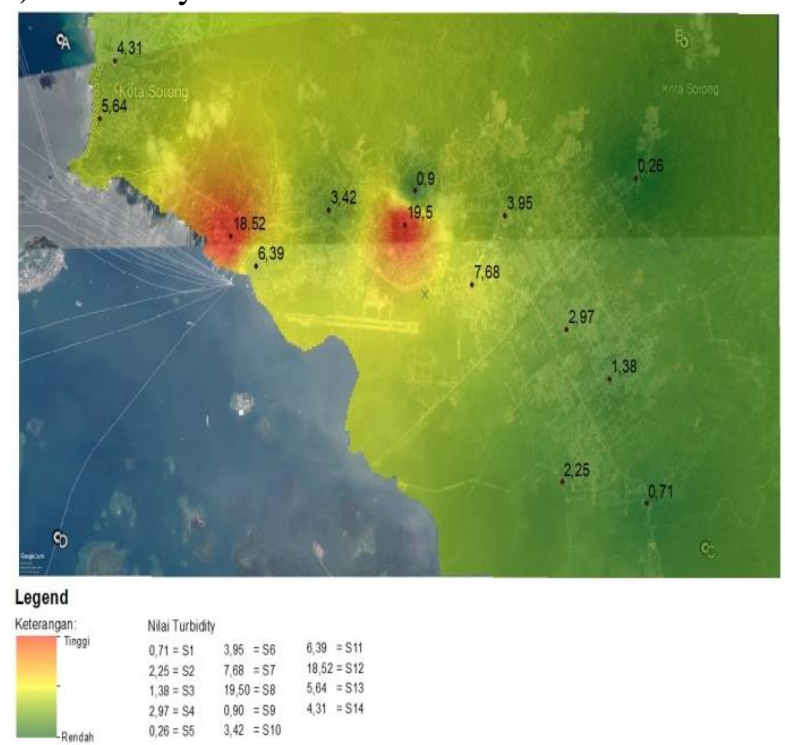

Gambar 6. Kontur nilai Turbidity penelitian

Dari gambar kontur untuk parameter turbidity (kekeruhan) diatas, nilai kekeruhan tertinggi yaitu 19,5 NTU pada titik S8 dimana titik tersebut berlokasi di Jl. F. Klasuat Malanudengan titik koordinat dengan jarak 2.335,79 meter dari garis pantai, dan nilai kekeruhan terendah yaitu 0,26 NTU berada pada titik S5 dimana titik tersebut berlokasi di Kampung Bugis Km.10 dengan jarak 6.089,31 meter dari garis pantai. Dilihat dari gradasi warna parameter kekeruhan untuk sumur bor warga Kota Sorong pada titik penelitian nilai kekeruhannya dominan rendah.

\section{Peta Kontur Parameter Kimia}

Dari gambar kontur untuk parameter Besi (FF) diatas, nilai fe tertinggi yaitu $3,8 \mathrm{mg} / \mathrm{L}$ pada titik $\mathrm{S} 7$ dimana titik tersebut berlokasi di Melati Raya $\mathrm{Km} .9$ dengan jarak 2.382,56 meter dari garis pantai. Dilihat dari gradasi warna parameter fe untuk sumur bor warga Kota Sorong pada titik penelitian lebih dominan rendah atau nilai fenya rendah. 
a) $\mathrm{FE}$

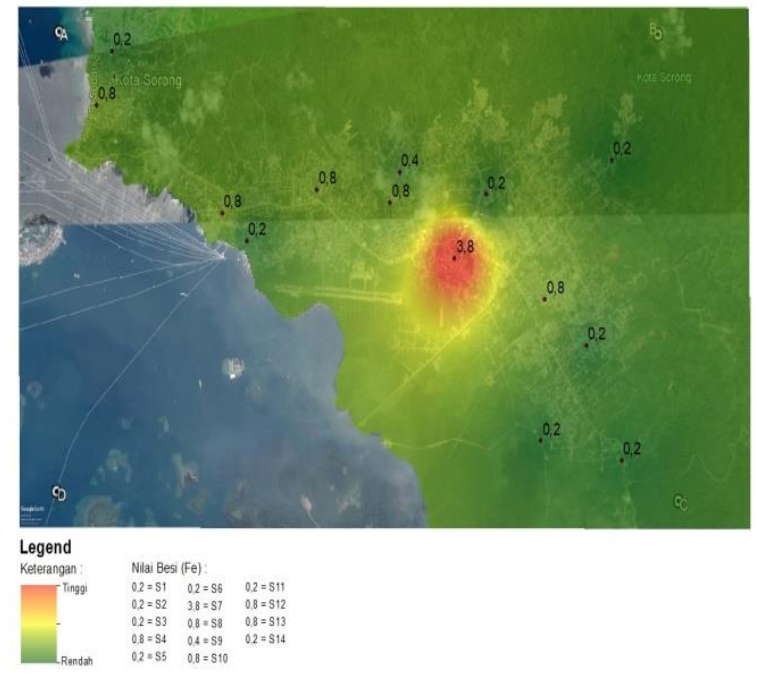

Gambar 7. Kontur nilai Besi (FE) penelitian

b) $\mathrm{pH}$

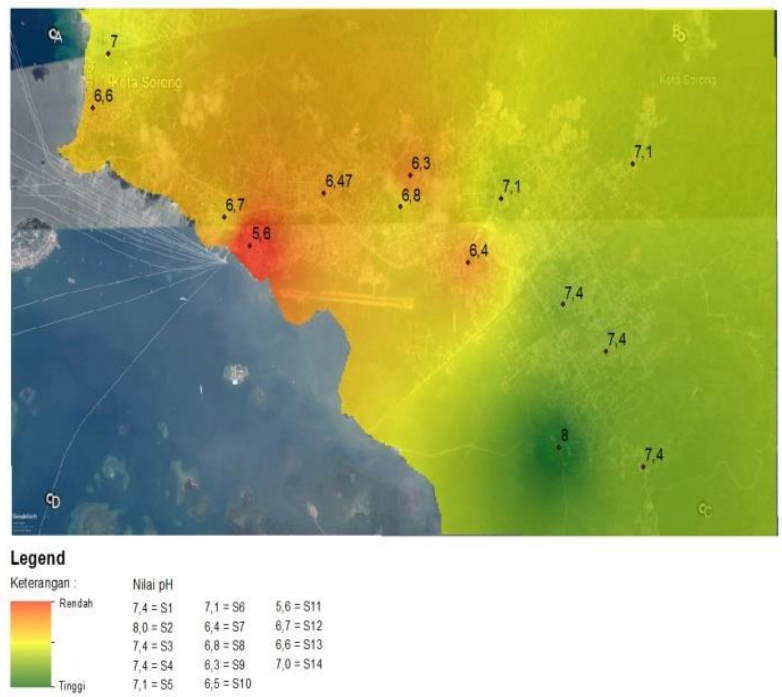

Gambar 8. Kontur nilai $\mathrm{pH}$ penelitian

Dari gambar kontur untuk parameter $\mathrm{pH}$, nilai pH tertinggi yaitu 8,0 pada titik $\mathrm{S} 2$ dimana lokasi titik tersebut berlokasi di Moyo Km.13 dengan titik koordinat dengan jarak 2.358,38 meter dari garis pantai, dan nilai $\mathrm{pH}$ terendah yaitu 5,6 berada pada titik S11 dimana titik tersebut berlokasi di Jl. Fery dengan jarak 438,65 meter dari garis pantai. Dilihat dari warna kontur pada parameter $\mathrm{pH}$ sumur bor warga Kota Sorong pada titik penelitian didominasi dengan $\mathrm{pH}$ relatif tinggi atau cenderung bersifat basa. c) $\mathrm{DO}$

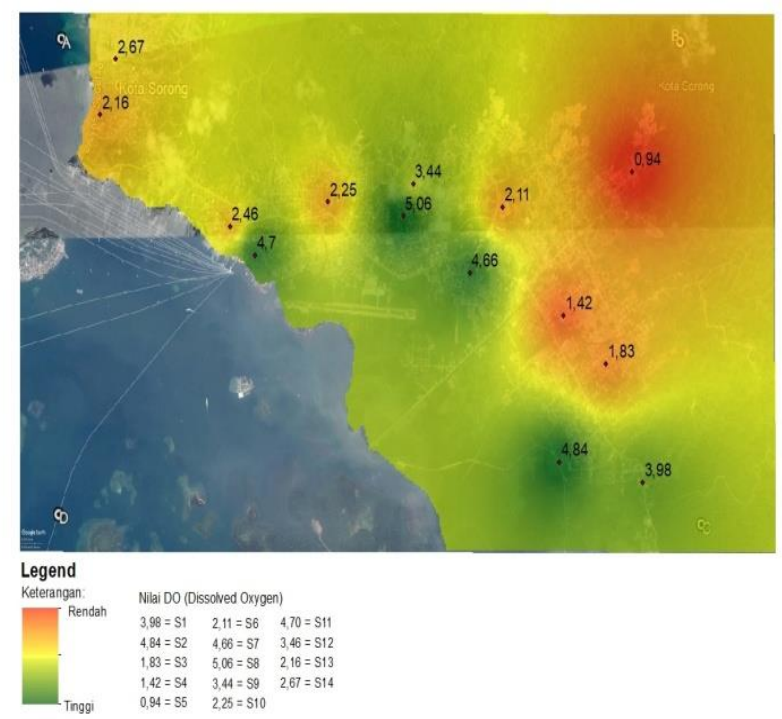

Gambar 9. Kontur nilai DO penelitian

Dari gambar kontur untuk parameter DO (Dissolved Solid) diatas dapat disimpulkan bahwa nilai DO tertinggi yaitu $5,06 \mathrm{mg} / \mathrm{L}$ pada titik $\mathrm{S} 8$ dimana lokasi titik tersebut berlokasi di Jl. F. Klasuat Malanu dengan jarak 2.335,79 meter dari garis pantai, dan nilai DO terendah yaitu $0,94 \mathrm{mg} / \mathrm{L}$ berada pada titik S5 dimana titik tersebut berlokasi di Kampung Bugis Km.10 dengan jarak 6.089,31 meter dari garis pantai. Dilihat dari warna kontur pada parameter DO sumur bor warga Kota Sorong pada titik penelitian memiliki nilai DOnya didominasi relatif tinggi.

\section{Kesimpulan}

Berdasarkan hasil penelitian yang telah dilakukan, maka dapat ditarik kesimpulan

1. Bahwa $28,57 \%$ titik sampel yang memenuhi baku mutu kelas II, III, dan IV, dimana titik tersebut merupakan titik S2 yang berlokasi di Moyo Km.13, titik S7 berlokasi di Melati Raya, titik S8 berlokasi di Jl. F. Klasuat Malanu, titik S11 berlokasi di Jl. Fery, dan 21,43\% yang memenuhi baku mutu kelas III, dan IV, dimana titik ini merupakan titik S1 yang berlokasi di Km.14, titik S9 berlokasi di Kampus UMS, titik S12 berlokasi di Jl. Sultan Hasanudin, dan $50 \%$ titik sampel yang hanya memenuhi baku mutu kelas IV dimana titik tersebut merupakan titik S3 yang berlokasi di Jl. Dorowati Km. 12, titik S4 yang berlokasi di Jl. Melati 2 Harapan Indah, titik S5 yang berlokasi di Kampung bugis Km.10, titik S6 berlokasi di Rawa Indah, titik S10 berlokasi di J1. Masjid Raya HBM, titik S13 berlokasi di RSUD Kab. Sorong, dan titik S14 yang berlokasi di Rufei. 
2. Gambaran kualitas air sumur bor warga Kota Sorong berdasarkan hasil pemetaan yaitu hasil pengukuran parameter dengan gradasi warna yang mendekati kehijauan nilai parameternya baik (memenuhi baku mutu), sedangkan hasil parameter dengan gradasi warna yang mendekati kemerahan maka nilai parameter tersebut tidak memenuhi baku mutu. Dengan parameter TDS $100 \%$ memenuhi baku mutu, pH 92,8 \% memenuhi baku mutu, FE $50 \%$ memenuhi baku mutu dan parameter DO untuk kelas II $25 \%$ memenuhi baku mutu, Kelas III $21,4 \%$ memenuhi baku mutu, dan 50\% memenuhi baku mutu untuk kelas IV.

\section{Referensi}

Effendi, H. (2003). Telaah Kualitas Air. Kanisius. Yogyakarta.

Hasrianti, Nurasia. (2014). Jurnal : Analisis Warna, Suhu, $\mathrm{pH}$ dan Salinitas Air Sumur Bor di Kota Palopo. Palopo : Universitas Cokroaminoto Palopo.

Peraturan Pemerintah Nomor 82 Tahun 2001 Tentang pengelolaan kualitas air dan pengendalian pencemaran air 